\title{
Legado de Caim: a jornada brasileira do Living Theatre (1970-71)
}

Caim's legacy: the Brazilian journey of the Living Theatre (1970-71)

\section{Alessandra Vannucci}

A Judith Malina, in memoriam

Alessandra Vannucci

Professora da Escola de Comunicação e do PPGAC da UFRJ

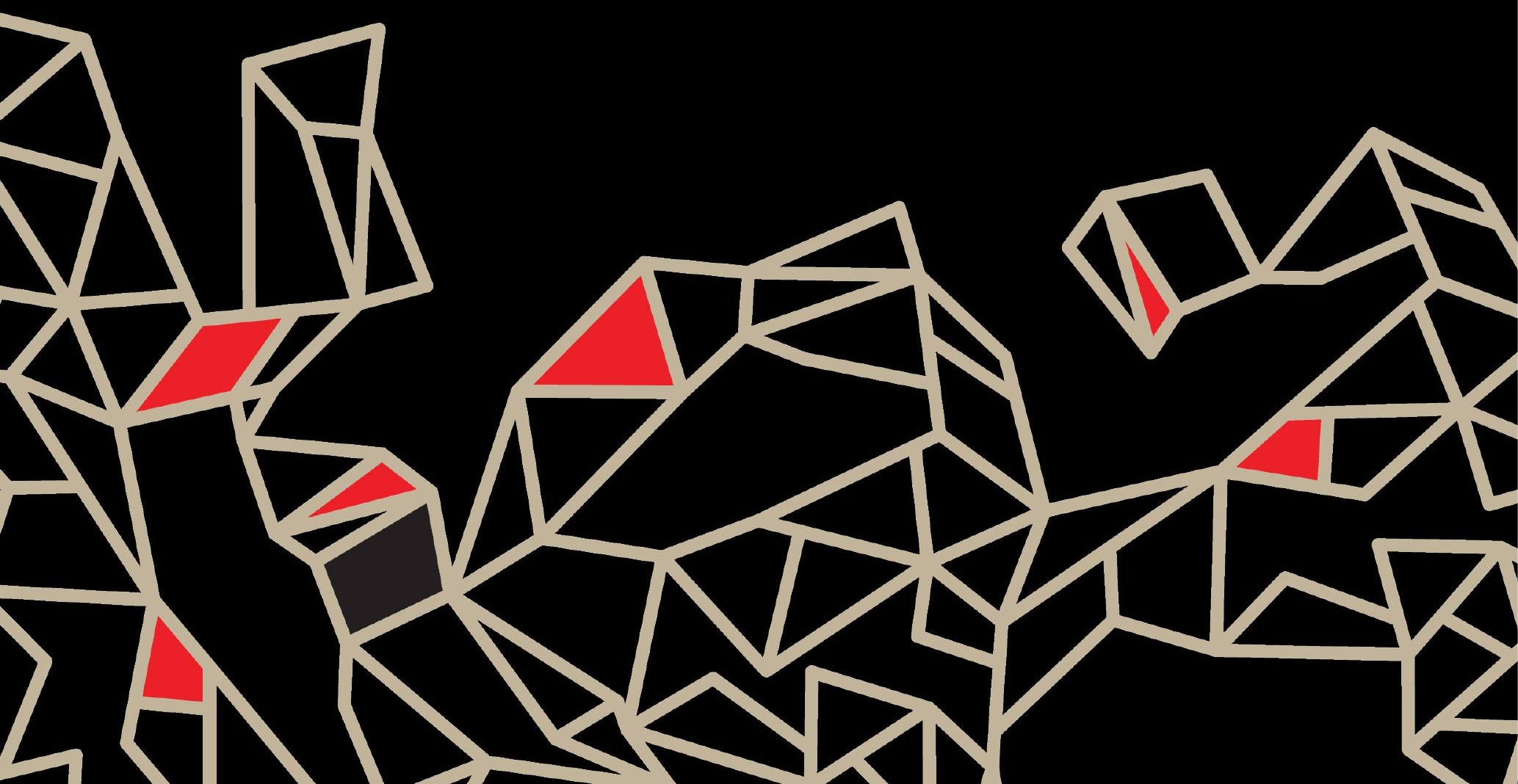




\section{Resumo}

Na trajetória do Living Theatre, companhia teatral de origem norte-americana, desde 1964 nômade por opção, a viagem ao Brasil de 1970 a 1971 proporcionou, por meio de experiências extremas de opressão - como a detenção -, a descoberta de novas táticas de ativismo estético-político. Focando um processo teatral que não aconteceu como espetáculo, mas provocou uma espetacular auto exposição dos dispositivos de repressão do regime militar, o artigo se propõe analisar estruturas constitutivas daquela fase da história da nação.

Palavras-chave: Living Theatre, atos públicos, Brasil, regime militar.

\section{Abstract}

In the trajectory of the Living Theatre, an American theater company nomadic by choice since 1964, the trip to Brazil in 1970 to 1971 provided through extreme experiences of oppression - such as detention - the discovery of new strategies of aestethic-politic activism. Focusing on a theatrical process that did not happen as a show, but sparked a spectacular self-exposure of the military dictatorship repression devices, the paper aims to analyse constituent structures of that stage of Brazilian history.

Keywords: Living Theatre, public acts, Brazil, military dictatorship.

\section{8: o teatro está nas ruas}

The plot is the revolution ${ }^{1}$

(Paradise Now, 1971)

Entoando um mantra libertário, uma caravana de espectadores toma de assalto o Palácio dos Papas, onde alguns deles agarram-se nas grades e se lançam, aterrissando em redes de braços; o coreógrafo Maurice Béjart descamisado, em coletiva de imprensa, ameaça não dançar na data programada

1. A trama é a revolução. 
pelo Festival de Avignon por solidariedade aos companheiros Julian Beck e Judith Malina, cuja apresentação foi cancelada pela produção; estupefato sob o sol a pino daquele implacável mês de julho de 1968, Jean Vilar, criador e diretor do Festival, escuta jovens rimarem seu nome com o do ditador português Salazar. Pivô do "escândalo" - assim noticiado pelo rádio na reportagem sobre os "acidentes de Avignon", de 25 de julho de $1968^{2}$-, o grupo americano Living Theatre, cujos integrantes dois meses antes estavam em Paris, na linha de frente da multidão de insurgentes, estudantes, trabalhadores e atores que, cantando a Internacional e agitando bandeiras anarquistas, haviam invadido o venerável Théâtre de l'Odéon. O bando pretendia ocupar a Torre Eiffel, mas Beck convencera os demais de que seria mais estratégico ocupar um teatro, por ter em sua estrutura retratado o elitismo social e a separação entre arte e vida. A ocupação romperia, segundo Beck, tais barreiras; irromperia na convencional partilha de poder entre palco e plateia, fazendo daquilo "um lugar de teatro vivo, onde qualquer um pode tornar-se ator" (BECK apud TYTELL, 1995 , p. 232), ou seja, todos usufruem do mesmo direito ininterrupto à palavra. Toma-se a palavra em 1968 - como havia se tomado a Bastilha em 1789, sugere Michel de Certeau (1994, p. 40). Um comunicado do Comité d'action révolutionnaire (MIGNON, 1999, p. 286) explicita: "A ação não se dirige contra uma pessoa ou um repertório, mas contra a cultura burguesa e sua representação teatral. O Odéon cessa de ser um teatro. Torna-se um local de encontro de trabalhadores, uma comuna revolucionária". O próprio Jean-Luis Barrault, diretor do Odéon, ao ver a inesperada cena, exulta: "que maravilhoso happening!" (MIGNON, 1999, p. 285). Em sua Declaração para a ocupação do Odéon, Beck clama estar assistindo ao mais belo espetáculo jamais visto em um teatro: a revolução em sua forma não violenta, através da "libertação verdadeira" dos modos de convivência, um primeiro passo para a libertação da arte, da cultura, das universidades. "Está na hora de ir ao encontro do povo, na rua, para que conheça as suas possibilidades de ser" (BECK apud QUADRI, 1982, p. 257). No dia seguinte, o acervo de figurinos do teatro é saqueado e os manifestantes enfrentam a polícia vestidos de piratas e prin-

2. Disponível em: <http://fresques.ina.fr/en-scenes/fiche-media/Scenes00420/scandale-de -paradise-now-du-living-theatre-au-festival-d-avignon.html>. Acesso em: 30 jun. 2015. 
cesas. O teatro vai às ruas, a rua irrompe no teatro. Eis a ideia que engendra o percurso do Living na década seguinte: o espetáculo como happening, ato público, ensaio da revolução possível. A trama de Paradise now, que o grupo então gestava para estreia em julho do mesmo ano no Festival de Avignon, é a própria revolução em ato: paraíso agora. No final da peça, as portas da sala se abririam ao convite: "O teatro está nas ruas. As ruas pertencem ao povo. Liberte o teatro. Liberte a rua. Comece!" (TYTELL, 1995, p. 228). Os espectadores irromperiam na cidade não porque o espetáculo acabara, mas porque somente ali começaria sua verdadeira libertação.

Como desencadear tal processo? Anotações redigidas por Beck e Malina transcrevem as vozes que compõem a "viagem labiríntica" dos ensaios de Paradise Now, segunda montagem do Living (após Mysteries and small pieces) em regime de criação coletiva. A escrita dos cadernos é simultânea aos ensaios: "não são um diário, são um documentário" do processo criativo, desde a primeira ideia até a marcação da luz na noite anterior à estreia, passando "pelas pedras, pelas armadilhas, pelo silêncio abismal, [...] por cada circumnavigação da viagem" (BECK apud QUADRI, 1982, p. 261). O registro funciona como repertório, sendo repetidamente visitado para a construção do espetáculo. Analogamente ao processo criativo, a peça é concebida, segundo Beck (apud QUADRI, 1982, p. 241) como uma via de mão dupla, "da multiplicidade à unidade e da unidade à multiplicidade"; como uma viagem espiritual e política que não ilustra, mas compartilha com os espectadores experiências performativas, sem duração previamente estabelecida, de "ascensão vertical rumo a revolução permanente” (apud QUADRI, 1982, p. 241). Imagens e ações cênicas, técnicas performativas e terapêuticas, são aplicadas como táticas de provocação e contágio (ao modo alquímico de Artaud) para desencadear progressivas sessões libertárias - degraus de conscientização que Malina, em seu diário, em 23 de maio de 1968, denomina de Rituais Políticos e declina no plural: "o ritual em que a gente se reconhece recíproca/politicamente; o ritual em que a gente recomeça a falar; o ritual em que a gente se reúne; o ritual em que a gente desmistifica; o ritual em que a gente muda; o ritual em que a gente se liberta; o ritual em que a gente desarticula as tiranias; o ritual em que a gente acha saídas; o ritual em que a gente se eleva; o ritual em que a gente come da árvore da vida" (MALINA apud QUADRI, 1982, p. 
254). Segundo Beck, "não seria possível fazer uma peça chamada paraíso agora e não ser livre ou não tentar libertar qualquer um que não o fosse; para fazer com que isso pudesse acontecer, conjuramos a ação de forças misteriosas: a influência das cores, a sabedoria do Livro das Mudanças, a excitação das energias dos Chacras, a imagem sagrada do mundo, as visões da Cabala. Energizávamos o corpo segmento por segmento com sons, visões e ritmos que levavam os atores-xamãs e o público ao transe. Neste espaço livre, talvez pudéssemos entrar no domínio do Teatro Livre" (BECK, 1975, p. 94). O termo free theatre propõe uma prática de improvisação teatral inspirada no free jazz, isto é, temas abertos para que o público possa compartilhar, responder, repitir, mantendo a obra em estado de processo criativo. "Formas de paraíso brotam de opressões violentas, como o jazz; neste campo magnético, cada um, a cada noite, cria tudo de novo", anota Beck em seu caderno em 31 de janeiro de 1968 (BECK apud QUADRI, 1982, p. 273). A ideia era agenciar o magnetismo dos presentes em uma deriva performativa sem controle, na qual ninguém imitaria o drama de alguém ou falaria em nome de outro, mas cada um, como si mesmo, aconteceria com seu próprio drama - o que é bem descrito pela palavra happening. Não se trataria de representar um papel, mas de manifestar a singularidade, realizando-se como parte de uma comunidade que se expressa em espetáculo. O deslocamento de corpos dos lugares e funções previstas (atores de um lado, espectadores de outro; ficção do palco, vida na rua) revelaria por si só a contingência de qualquer ordem social. $O$ simples fato do espectador se emancipar da condição de passividade imposta pelo regime da representação denunciaria a ausência de fundamentos de qualquer opressão. "Não haverá teatro livre até que haja prisioneiros no mundo. Teatro Livre é arma secreta do artista militante", concluia Beck (1975, p. 95).

Após duas apresentações e a marcha pelas ruas de Avignon, Paradise now foi vetado pela direção do festival e a proposta do grupo de apresentá-lo gratuitamente nas ruas provocou imediata detenção na escola onde estavam hospedados. Contando, nesta altura, com 30 integrantes de diversas nacionalidades e suas crianças, o Living formava uma tribo cujos modos de vida pareciam coerentes à sua utopia social; esta, por sua vez, embasava e se expressava com intensidade na missão teatral. Era contagiante, pois mesmo reduzido à impotência, o grupo não parava de atrair novos membros. A 
deportação da venerável cidade dos papas em camburões da polícia foi o gran finale que selou, com imprevista emblematicidade, não só o espetáculo proibido, mas todo o movimento insurrecional daquela memorável primavera. Um passo além da libertação das consciências levaria à guerrilha. Em 1969, a viagem pelos EUA obrigou o grupo (que se deslocava entre fábricas em greve, edifícios ocupados, campus universitários) a ter contínuos confrontos com a polícia. A esperança de que aquela energia excepcional fluísse na criação de formas diversas de organização social, rumo à utopia anárquica da convivência humana sem classes e sem nações, gerava paradoxalmente 0 "enorme desespero" (era assim o título do diário da Judith daquele ano) ao ver que o movimento, diante do recrudescimento das forças da repressão, poderia perder o caminho pacifista e recorrer às armas. E "a luta armada, resultando do apoio às lutas de libertação dos povos do Terceiro Mundo, põe historicamente o problema de como acabar com todas as ditaduras", pondera Judith em tempos mais recentes (apud VALENTI, 1995, p. 165): pois "a história ensina que após uma revolução conduzida com modos violentos, sempre emerge um novo tirano".

Neste momento, em que o Living Theatre era "catapultado na História" (brinca Judith em seu diário de 22 de junho de 1970) com dois livros dedicados à sua trajetória na Itália e convites de diversas instituições para que fixasse residência na Europa, o grupo, ao contrário, embarca para mais uma viagem, dessa vez ao Marrocos. A vida itinerante, que havia sido por alternativa existencial até então, é assumida como um modus vivendi nômade coerente aos fundamentos ideológicos dos membros. Por um lado, desde a década de 60, a itinerância dos artistas proliferava no imaginário da contracultura, e sua produção cultural em autonomia dos circuitos da indústria cultural (HALL, 1970, p. 32); na ampla difusão de notícias em mídias underground (rádios, jornais e, no caso dos Beck, correspondência) era veiculada a percepção de que uma enorme rede pacifista estava unindo as comunidades hippies pelo mundo. Sendo uma alternativa viável, a viagem de um festival, cidade ou nação para outro permitia, segundo o grupo, como explica em sua Action declaration (apud BINER, 1972, p. 225) escapar das armadilhas constituídas pelos teatros enquanto edifícios, pelas formas convencionais da representação, pela dependência do sistema dos circuitos e pela institucionalização, que 
comportaria aceitação dos aparatos de controle. A assunção do nomadismo como opção é, portanto, um dispositivo de guerrilha, pois permite escapar da repressão, e um comportamento messiânico, já que desarticula as relações com o espaço e o tempo instituídos por fronteiras e calendários e permite a entrada em um tempo revolucionário, de preparação do mundo a porvir, que pulsa no interior do tempo cronológico, capaz de resignificar a vida cotidiana e potencializá-la como processo criativo permanente, desvinculado da produção de espetáculos. $O$ deslocamento propiciaria um mergulho em si franqueado de marcos civilizatórios, cada vez mais autêntico à medida que se aprofundava em experiências energizadas por mistérios e rituais de culturas pré-capitalistas, como é o caso da convivência, em Essaouira, com a tribo nômade de mendicantes gnaoua, com os quais compartilham mantras e técnicas de respiração para conseguir estados de transe e maconha. A saída do Marrocos no prazo de 24h, sob voz de prisão, interrompeu a experiência.

Durante a sessão analítica que ocupa a navegação ao longo da costa da Itália, o coletivo delibera pela desagregação como tática paradoxal de manutenção do Living e pela "descentralização" em quatro células com destinos antípodas, visando "atacar a estrutura por todos os lados" (Action declaration, apud BINER, 1972, p. 226). Haviam surgido modos divergentes de conceber a revolução no grupo; buscou-se uma forma de resolver o conflito em modo anárquico. Em 1971, segundo Malina (apud VALENTI, 1995, p. 168), uma parte do grupo mais New Age, considerando que somente o desenvolvimento espiritual individual poderia mudar o mundo, optou por uma residência de meditação na Índia; uma parte mais pop permaneceu na Europa, investindo na revolução psicodélica (em Londres) e no environmental theatre (em Berlim); enquanto a quarta célula "desejando seguir na ação política direta e pôr o teatro a serviço da revolução não violenta" (apud VALENTI, 1995, p. 168) encarou o Brasil mergulhado nas trevas do regime militar. A action cell se resumia aos Beck e à filha de seis anos, Isha. $\mathrm{O}$ convite foi de Zé Celso e Renato Borghi (que os procuraram em Paris para comunicar o sofrimento dos artistas brasileiros censurados, sequestrados e exilados pela repressão na esperança de que o Living pudesse fazer alguma coisa) e tocava uma corda sensível - uma idealística necessidade de se pôr a serviço dos menos afortunados. Mas não só. $O$ chamado brotava também da convicção do papel 
crucial, que após o fracasso humanista do "primeiro mundo" e de sua tardia réplica norte-americana assumiria então na história o "terceiro mundo" - especialmente os países ex-coloniais, cujas lutas de libertação absorviam as expectativas revolucionárias universais. A convocação dos artistas para que empregassem "seus músculos e cérebros em outra direção, para inventar o homem total que a Europa foi incapaz de fazer triunfar", no último parágrafo de Os danados da terra (relato de Franz Fanon, de 1961, sobre as atrocidades da guerra de independência algeriana, leitura obrigatória na época) alimentava a compreensão de que qualquer luta de libertação é fundamentalmente um fenômeno cultural. Assim como na poesia e cinematografia do amado Pier Paolo Pasolini, a opção estética pelo "imundo estupendo sol" dos países do terceiro mundo (entre os quais o Brasil, visitado em março de 1970 e objeto do apaixonado poema Hierarquia [PASOLINI, 1971, p. 205-209]) significava também abdicar da degeneração da língua, da cultura, da política e da paisagem, enfim, degeneração da realidade, em ato na Itália capitalista.

Sob esta luz, a viagem ao Brasil representava uma missão essencial na diáspora do Living, pois significaria a oportunidade de conhecer outra "realidade" - palavra usada nos diários de Judith e Julian a partir de 1970, em português e entre aspas, entendendo a condição de sofrimento do povo brasileiro como consequência do imperialismo europeu. Essa condição era sintetizada pelo locus explosivo da favela, emblema da deterioração irreversível do capitalismo e do ato insurrecional dos oprimidos que irrompem no mapa das metrópoles. A missão no Brasil previa "ajudar na luta pela libertação, porque está na hora de os artistas levarem o conhecimento e o poder de suas artes aos danados da terra", como declarado ao jornal "Le Monde", em 14 de julho de 1971, aniversário da tomada da Bastilha (MALINA, 2008, p. 235), logo após o regresso. $O$ risco de se tornar alvo da repressão fazia parte da empreitada; era um risco frequente na vida do casal, que neste caso se preparou estudando, além de português como ferramenta básica de autodefesa, as razões históricas e raízes antropológicas dos dispositivos repressivos da sociedade brasileira. Neste momento, o ciclo de contos O legado de Caim (Das Vermächtnis Kains, 1870-77), de Leopold von Sacher-Masoch, uma velha frequentação da Judith que carregava uma versão ilustrada desde 1956, ganhou novo sentido à luz da leitura de obras sociológicas como Casa grande \& senzala 
(traduzido para o italiano, em 1965, com o título Il padrone e lo schiavo), de Gilberto Freyre (2002); tal sentido norteou intelectualmente a viagem.

A partir da dialética hegeliana da recíproca dependência nas relações de dominação, a ideia de que o elemento dominador só existe na medida de linguagem que Ihe atribui o dominado é desenvolvida no livro de Barthes (1971). Para cada dominador sádico existe um dominado masoquista, que sente a necessidade de buscar seu parceiro para cumprir a narrativa. Em As criadas, de Jean Genet, encenado pelo Living em 1965 logo após uma longa detenção em New Jersey, Genet identifica explicitamente a servidão com o prazer sadomasoquista da sujeição. O escravo não pode ser o patrão enquanto não possui os seus bens, imitando-o: sua admiração empodera o opressor como modelo e objeto de desejo sexual. A ideia cardeal das obras que compõem o Legado de Caim como uma constelação incompleta é que a complementaridade erótica entre dominador e vítima estrutura não somente a sexualidade, mas todos os níveis sociais (Estado, Propriedade, Dinheiro, Trabalho, Amor, Morte). Sacher-Masoch escreveu somente alguns contos sobre o amor (Venus in furs) e sobre a propriedade em que as figuras linguísticas da sujeição ganham, em chave romântica, uma perceção fantasmagórica das consequências, versando na abnegação fetichista com que o escravo carrega todos os devires humanos de "homem crucificado, sem amor, sem propriedade, sem pátria, sem querela, sem trabalho" (SACHER-MASOCH apud DELEUZE, 2009, p. 12) e, nesta condição fantasmática, absorve a fala obscena dos seus carrascos. A neutralização da realidade que se faz cada vez mais impossível e sua suspensão em fantasma - por autodefesa, segundo Lacan, que chama o mecanismo forclusion - constitui a herança endêmica dos crimes e sofrimentos que pesam sobre a humanidade: o legado de Caim. Neste sentido, parece claro o entendimento de que "a chave para exorcizar o legado da violência é a revolução sexual" (BECK, 1975, p. XXX).

Em Casa grande \& senzala (2002), Freyre descreve com clareza a natureza erótica da mais influente matriz das relações sociais no Brasil: "O sadismo de senhor e o correspondente masoquismo de escravo, excedendo a esfera da vida sexual e doméstica, têm-se feito sentir através de nossa formação, em um campo mais largo, social e político" (p. 123); no entanto, a descrição eufemística da dialética sadomasoquista que rege o sistema es- 
cravocrata nos termos recíprocos da "cordialidade" do dominador contra a "docilidade" do dominado parece anular a realidade em nome da manutenção do fantasma do bom senhor, fixado na memória afetiva do autor, já menino de engenho. "Sutileza" e "adaptabilidade", termos que Freyre usa para descrever a experiência colonial portuguesa no Brasil, são características atribuídas por Foucault (1989, p. 48) ao poder quando argumenta que prazer e poder não são incompatíveis, mas interconexos por mecanismos de incitação recíproca entre vítima e carrasco, que visam substituir a memória física da violência. Em um dos ensaios transcritos no diário de trabalho de Beck de 1971, em Ouro Preto, Freyre aparece citado por Judith porque, "qual porco fascista, admira o papel masoquista dos escravos brasileiros e, qual patrão inteligente, sabe inverter a situação e afirma: sem escravidão não haveria desenvolvimento no Brasil" (MALINA apud BECK, 1975, p. 263). Em nome da afirmação da miscigenação racial, que só poderia ter acontecido de forma pacífica em um sistema democrático - o que evidentemente não ocorreu -, Freyre omite, segundo Judith, o nexo entre regimes de opressão (no passado e no presente) e naturaliza a submissão como condição necessária à "realidade." Essa intuição a leva a propor, no mesmo ensaio, uma diferente distribuição dos papéis. 0 reconhecimento de si no pacto sadomasoquista e a recusa do escravo de performar o papel de vítima dócil poderia significar a interrupção do sistema da violência que conduz à nova violência, como inevitável solução; passando a assumir outro papel, o subjugado poderia compreender-se capaz de mudar a "realidade" e achar "outra saída", como sugere Beck na Mensagem aos atores:

Você quer alimentar os famintos. Você quer libertar os explorados. Você quer acabar com todo sofrimento. Você não imagina como isso pode ser feito sem violência. Teria prazer de sair por aí e meter bala no coração de um policial? Sentiria prazer físico em estrangular um banqueiro, um patrão? Pode até ser que sim, no sentido de que você sentiria alivio em continuar vivo - assim reagimos há dez mil anos. Se a resposta for não, não o faça nem encoraje outras pessoas a fazê-lo. Não confie em violência. Encontre outra saída (BECK apud TROYA, 1993, p. 30).

Desde antes da partida, a viagem configura-se como uma missão revolucionária dotada de uma específica estratégia não violenta: uma campanha de guerrilha teatral que visava "saturar" o dispositivo sadomasoquista, isto 
é, torná-lo perceptível nas principais instituições de poder. Era preciso fazer com que o povo, anestesiado pelo fantasma da cordialidade, se reconhecesse no papel do escravo e sentisse, conscientemente, a dominação - o prazer masoquista de ser dominado e o prazer cruel de dominar e infligir dor - para compreendê-la. Ao modo de Artaud, a experiência da crueldade seria portal do conhecimento e da transformação, pois, ao modo de Brecht, somente assumindo outro ponto de vista é que a classe dominada aprenderia a não mais imitar a classe dominante. Permitindo essa troca de papéis, o teatro seria a arma, o "cavalo de madeira" que irrompe na cidade. "Acontece na realidade", anuncia Beck a nova peça, que intitula de $A$ Grande Beleza. "Precisamos ocupar uma área em algum lugar. Um enclave anárquico de milhares de pessoas. Temos que fazer de modo que todos os soldados desertem, todas as portas se abram, todas as pessoas possam comer e toda a matança termine. Este é o roteiro do único espetáculo que me interessa" (BECK, 1975, p. 237). Dias antes da partida, a trama já estava sendo esboçada na toalha de mesa do café Morvain, em Paris: um mapa com muitas cenas de teatro acontecendo simultaneamente nas ruas e praças de uma cidade ao longo de uma semana, o dia todo, noite adentro "até que mudem as vibrações dos ambientes", anota Judith em seu diário de 27 de julho de 1970.

Em São Paulo, o desencontro com Zé Celso e com o grupo Oficina, em fase de reorganização estética e de elenco, releva compreensões divergentes do trabalho, dos meios de conduzi-lo e dos tempos à disposição. Nas transcrições do mês e meio de ensaios, enquanto é relatada e desnudada a mecânica das relações interpessoais, o esforço da autoanálise transcende em interpretação do mundo, reconhecendo na relação patrão-escravo também a relação-base das formas de espetáculo possíveis. No caso das brasileiras, o luxo solene das formas representacionais, como o Carnaval institucionalizado em espetáculo no Rio de Janeiro, reproduz, segundo Beck, a distância social; enquanto isso, no carnaval popular e nas cerimonias afro-brasileiras, o povo irrompe no espaço comum em estado de contágio sensorial, provocando a explosão de energia erótica e o exorcismo dos demônios. "Mudar o som da música na rua, cantar, dançar, até que se possua uma força suficiente para mudar a vida", anota Beck (1975, p. XXIX) após uma visita a um terreiro de Umbanda em São Paulo. O encontro com Jean Genet na casa da Ruth Es- 
cobar aponta o caminho: "Genet deixou a arte para trás. Respondendo ao clamor dos danados da terra, ele vai para onde os ouve gritar: de prisão em prisão, desafiando a zombaria, ousando ser completamente mal compreendido" anota Judith em seu diário nos primeiros dias de setembro de 1970 (MALINA, 2011). Três dias antes do Natal de 1970, uma ação com estudantes da USP marca a estreia do grupo na rua - uma rua de terra na favela do Buraco Quente, perto do aeroporto de Congonhas, localizada durante amplo périplo nas periferias para gravar respostas dos moradores sobre suas vidas, problemas, esperanças. "Caminhamos vinte anos para chegar aqui', comenta Julian, segundo relata Judith em seu diário de 22 de dezembro de 1970. "Entramos em procissão. O sol está forte e quente. Tocamos a nossa música com pedaços de bambu. As crianças nos seguem descalças e alegres. Estamos excitados, porque este é o nosso primeiro espetáculo de rua, é nossa entrada para o outro lado do mundo, é nossa noite de estreia sob o sol do meio-dia" (Ibidem). Apresentam sete cenas narradas e ilustradas por imagens (uma história sobre dinheiro, uma história sobre amor, uma história sobre propriedade, uma história sobre um rei, uma história sobre a guerra, uma história sobre a morte, uma história sobre o futuro) interpostas por ações emblemáticas da relação escravo-patrão, como assinar um pacto de servidão e se acorrentarem uns aos outros. No texto que transcreve esta intervenção (Bolo de Natal para o buraco quente e o buraco frio), a palavra actors é sucessivamente corrigida por perfomers; da última ação, que consistiria em soltar os acorrentados, é dito que é um "ritual que deve ser performado pelos moradores da comunidade." Continua Judith em seu diário: "Vejo um homem emergir do povo, timidamente. Enquanto me desamarra, ele se inclina e sussurra: 'Amanhã o povo vai liberar todo mundo'. Livre, levanto as mãos do meu libertador e vamos nos unir ao círculo que vai se formando, emitindo um som de prazer absoluto" (MALINA, 2011). O contágio performativo, possível no espaço/ tempo compartilhado das ações propostas, é passagem para a emancipação do espectador, que ao decidir que vai tomar parte, de repente se reconhece como aquele que cria liberdade. A dramaturgia investe na flexibilidade do pacto cênico ao ar livre, onde o espectador também é livre de condicionamentos, que se adapta a descrever um jogo que ainda deve ser jogado; algo que não atende mais pelo nome de peça, mas de ritual, ressaltando sua função 
alquímica e transformadora. A estreia na favela coincide com a opção para a rua, não mais como alternativa, mas como conquista imprescindível à missão estética do grupo. A descoberta das possibilidades de comunicação alimenta planos mais ousados. Malina (2008, p. 167) registra: "assentados, incrédulos, ninguém fala por um instante; de repente, todos falam. Mal podemos acreditar que conseguimos, que ninguém nos impediu, que nada deu errado e que fomos bem compreendidos." Uma semana mais tarde, o Living negocia com a polícia a apresentação, no palanque montado na praça da comunidade do Embu, para os festejos do réveillon, do Ritual de transformação das forças demoníacas em forças celestiais. Diante da desconfiança do delegado, Judith garante, ensaiando o português, que pretendem transformar "o ambiente da praça numa atmosfera de alegria e celebração, com exercícios de som e movimento, sem palavras, sem estrutura alguma que possa identificá-lo como uma peça" (MALINA, 2011). Debaixo de chuva, sob os lustres festivos, o grupo performa um paredão de execução (duas filas de executores e vítimas, uns atirando com um revólver na cabeça dos outros que caem, repetidas vezes, em câmera lenta), uma ação de perseguição (em que os atores se chicoteiam com cintos) e a ação de bondage acima descrita (um ator amarrando o outro, que se submete ao dominador, até que o ultimo ator pede a alguém do público que o amarre) enquanto tambores tocam ritmos de marcha militar. $A$ polícia assiste curiosa, até mesmo cordial; entretanto, na narrativa de Judith, sua presença, revelada pelo brilho dos capacetes "como um círculo obscuro em volta do ritual", desvenda a relação antagônica entre vítimas e carrascos aos olhos do povo, que, "sente a realidade das nossas correntes como a sua própria". No entanto, o convite para que tome parte da narrativa, em todas as ações acima descritas, Ihe oferece oportunidade de assumir os papéis desde sempre repetidos, de opressor e oprimido, sentindo o prazer e a dor da violência, ou, então, de encontrar outra saída - como o homem do povo que espontaneamente, ao soltar Judith das amarras, consciente de seu poder revolucionário não violento, havia ousado dizer seu sonho: "o povo vai libertar todo mundo.' No palanque que havia ficado vazio, um cartaz encharcado anunciava os exóticos visitantes, "O Living Theatre de Nova York", relembrando-Ihe a rota. "O nosso barquinho pegou o mar", Julian observa; e Judith: "Fizemos o único trabalho realmente importante de nossa vida". 


\title{
1971: a cidade saturada
}

\begin{abstract}
Estou com o povo que vende seu suor, seus corpos, suas vidas para escapar da escravidão. Vivemos em um sistema que produz sofrimento, derramando de suas fábricas o oceano de dores onde morremos afogadas, cedo demais. O teatro é como um barco, pequeno. Mas a revolução é a inversão do sistema, é a mudança da maré. (BECK, Ouro Preto, 6 de maio de 1971, in BECK, 1975, p. 3)
\end{abstract}

No começo da década de 1970, Ouro Preto, então destino privilegiado de jovens artistas e ícone da cultura hippie pelo menos em julho de cada ano, por ocasião do Festival de Inverno, foi alvo do recrudescimento da repressão por parte do regime militar agindo em estilo faroeste com tiroteios, prisões e execuções sumárias. Marcada por séculos de opressão racial, sexual e de classe, a vila colonial, no coração das minas, apresentava-se, aos integrantes do Living que iam chegando a convite dos Beck meses antes do Festival onde idealizavam se apresentar, como um aglomerado de comunidades pobres, sem acesso à arte e exploradas por uma única fábrica de alumínio, em Saramenha. Ali, entre aqueles muros carregados da memória da escravidão, embaixo da fumaça altamente poluente da fábrica, pretendiam desenvolver o Legado de Caim. À comunidade, os gringos (austríacos, canadenses, alemães, portugueses, um peruano, além de três brasileiros) pareciam pacíficos, mesmo com seus hábitos extravagantes nos modos de vestir, comer, conviver. Instalados em uma casa-república organizada como comunidade aberta, os artistas espalhavam-se pelos becos, batiam ponto nos bares da Rua Direita, levavam crianças para brincar no Vale, ofereciam aulas de ioga na Praça Tiradentes, articulavam um encontro semanal de treinamento com atores locais na Casa da Ópera e um laboratório de arte na Escola Municipal de Saramenha. Ao longo de seis meses de intensa atividade, aprontaram material para uma centena de cenas site-specific distribuídas em um mapa da cidade desenhada em grande escala e pendurada na parede da sala, em vez de na canônica planta do palco. O mapa é ao mesmo tempo agenda e tática da especial guerrilha à qual o grupo se propõe. Por isso Judith lembra ao grupo que sua missão cotidiana é "tornar este mapa inteligível aos espec- 
tadores", isto é, encontrar modos de inspirar a comunidade para que "tome parte nas visões que performamos" (MALINA apud TROYA, 1993, p. 55). A ideia de performar uma visão registra o esforço de sair do regime representativo, em busca de uma comunicação sensorial que passe pelo olhar, sem excluir outros sentidos. Seis sonhos sobre mamãe, experiência realizada na escola de Saramenha em 1971, consistia em uma sequência de práticas imagéticas ou visões performadas, pensadas para afetar os corpos e suscitar a participação espontânea do público, fosse com a respiração coletiva visando "libertar o ar" da fumaça das fábricas ou com o voo de crianças "libertadas" acima das cabeças de seus pais operários, visando revelar o domínio patriarcal na base da pirâmide da opressão social. Percebe-se, na transcrição dos ensaios (longos debates noturnos escrupulosamente transcritos no caderno de trabalho do Julian), extremo cuidado para que a participação não ocorra através da aprendizagem e do consumo, reproduzindo, mesmo que cordialmente, hierarquias de domínio (onde ao fantasma do patrão somariase o fantasma colonial do estrangeiro), mas por meio do compartilhamento e fruição de experiências físicas de libertação. Mesmo preparadas, as visões não são marcadas no espaço representativo; pelo contrário, desarticulam as expectativas da visibilidade de modo a manter a estrutura aberta para incluir a ação dos espectadores em montagem simultânea; neste momento, as visões poderiam saturar, revelando a todos os presentes as estruturas de poder subjacentes. Segundo o emocionado relato de Judith, em algum momento "as mães, que são as mais oprimidas entre os oprimidos, sentem o verdadeiro significado das visões, mesmo sem analisá-la" (MALINA, 2011). Desse modo, os ensaios do Living em Ouro Preto tomam a forma de uma sessão de pesquisa ou treinamento ideológico, produzindo sentidos para "penetrar fundo nas raízes das diferenças" (Ibidem) e elaborando táticas para incitar uma produção de presença específica: as visões dos participantes no ambiente em que a cena se propõe saturar. O compromisso de expandir o espaço estético até abraçar a cidade inteira registrado no mapa implicaria, portanto, na multiplicação de pontos de vista sobre ela a medida que a autoria das visões fosse de fato compartilhada. "No Teatro da Alegria Criativa, Teatro da Cura, Teatro de Vida, Teatro de Rua, que é o teatro do nosso futuro, futuro que começa agora, tudo se baseia em como o teatro afeta os corpos" anuncia Julian Beck 
aos atores em Ouro Preto (apud TROYA, 1993). A comunicação sensível seria capaz de criar comunidades conscientes de sua potência subversiva, mesmo que temporárias, como as zonas autônomas de Hakim Bey; a revolução estética seria a arma secreta do artista militante da Maravilhosa Revolução Não Violenta. "Eis a nossa força - conclui Judith em suas anotações no diário de 14 de maio - colocar dúvidas no fantasma da inevitável fatalidade da história. Grandes mudanças virão depois".

A conjuntura política, entretanto, arma outro final. Dias antes de sua abertura, a direção do Festival desilude os artistas sobre a possibilidade de apresentar Legado de Caim na programação; logo depois, uma denúncia anônima justifica a irrupção do DOPS na república onde residem. São encontrados medicamentos, vitaminas, livros e o mapa da cidade, que aos militares parecem constituir evidências de atividades subversivas. Presos e soltos em seguida, os Beck voltam voluntariamente à Praça Tiradentes apinhada de jovens que comemoram o início do Festival; quando são novamente levados, desta vez sob acusação de detenção ilegal de drogas. Da cela do DOPS de Belo Horizonte, dias depois (em 10 de julho de 1971), Judith Malina descreve:

Um manto de tristeza caiu sobre o povo. Vi, em torno do monumento do mártir nacional, muitos jovens rostos olharem para nós. Todos eles sabiam, compreendiam a nossa provação. Acima deles, Tiradentes, o herói, barbado e de cabelos compridos como nós, com a corda ao pescoço. $\mathrm{O}$ símbolo da cidade, patrono da polícia militar e símbolo nacional. Nós, que estávamos sendo retirados do cenário do festival, éramos parte da cena, parte da noite inaugural, parte da desolação, parte da realidade, parte do homem que estava no monumento com a corda no pescoço. Nossa única, inesquecível cena para o Festival foi nossa partida. (2008, p. 50-51)

Enquanto aguardavam o julgamento, os dez atores encarcerados na Colônia Penal de Ribeirão das Neves criaram uma peça (Sonhos dos prisioneiros) com a participação dos presos, seus familiares e os guardas. Por resguardo ao casamento de ininterruptos 28 anos, o DOPS fez "papel de Cupido" (anota Judith bem-humorada, em seu diário do primeiro dia de prisão), concedendo ao casal Beck que ficasse preso no mesmo corredor e que passasse algumas horas do dia na mesma cela, onde escutavam rádio, estudavam, 
liam (uma tradução em português da Ilíada para Judith, jornais brasileiros que se ocupavam inclusive de seu caso para Julian) e escreviam. Assim como preencher o caderno é trabalho cotidiano para Julian, o registro autobiográfico do diário é ritual de Judith desde a infância, em diversas versões (além do diáro íntimo, um timeline, um caderno de anotações de trabalho e ainda, naqueles anos, um diário redigido em nome da pequena filha Isha, ainda não alfabetizada). Neste caso, a situação-limite a incitava a narrar os fatos do recente passado com especial urgência - uma terapia auto-aplicada, fosse para controlar os impulsos e transcender a rotina, fosse para compreender, analisar, fixar ou, eventualmente, esquecer os traumas vividos. A viagem, a aventurosa reunião da tribo na vila entre montanhas, o intenso processo criativo, a ameaça constante de repressão, o encarceramento e afastamento forçado da filha, a quase separação do casal à qual segue o nascimento da primeira neta nos EUA, são eventos intensos que brotam em páginas impregnadas de dramaticidade e de amor pela vida - mesmo que o corpo estivesse entre grades, a mão que escreve liberta o imaginário. Ao ler o diário que Judith Ihe havia mostrado, um jornalista do Estado de Minas o encaminhou para publicação em forma de folhetim. Assim, sabendo-se vigiada e possivelmente censurada, ela passou a escrevê-lo com o paradoxal destino da publicação em mente. Trata-se de uma escrita especialmente performativa. A adoção de uma postura autoral suspende o pacto de sinceridade; em vez disso, instala-se um tratamento sentimental, até mesmo melodramático, seja no que diz respeito à forma, seja aos conteúdos, talvez visando se aproximar do público leitor. Uma primeira instância ficcional mira projetar uma imagem positiva de sua autora - presa, porém boa mãe, boa esposa, e como cereja do bolo, boa prisoneira - e do grupo, que havia sido desmoralizado por causa de seus hábitos de vida hippie, objeto do escândalo em outras matérias naquele e em outros jornais. Em segundo plano, a insistência na rotina até pacata da reclusão, sem relato de violência ou tortura, enfatiza a vida como resistência e cuidado de si, mesmo em estado minoritário, ilustrando entrelinhas o discurso pacifista e anarquista. $\mathrm{Na}$ cela, com as suas companheiras, a personagem presa (Judith) adota hábitos amorosos de convivência que afetam, por contágio, ambientes contíguos como o dos guardas - cujos comportamentos a autora (Judith) observa, descreve e comenta com relativa liberdade. Deste modo, encarcerada, 
ela passa a vigiar os que a vigiam; acatando preventivamente a censura imposta por estar presa, pode encenar a si mesma naquele cenário, driblando uma possível repressão. Nessa coincidência entre vida e arte, o diário é uma performance articulada como tática de resistência. A sinceridade é suspensa em nome da possível performatividade retórica da palavra e da subjetivação no papel de presa dócil e bem relacionada com os seus carcereiros. "É tudo mentira", comentou em seguida a autora (MALINA apud LANA, 2013). Seus efeitos são clamorosos, pois a ficção subverte a verdade - imposta pelo saber público e conveniente ao poder opressor - de que se trataria de uma presa particularmente subversiva cujo encarceramento seria justificado como atitude corretiva. Porém, a subversão continua ocorrendo no diário publicado, sutilmente, sem enfrentar tal poder, ao contrário atribuindo-lhe tratamentos de cordialidade até mesmo no exercício da mais extrema violência. Assim, a dialética sadomasoquista que sustenta o dispositivo repressivo do cárcere torna-se claramente perceptível mesmo a leitores desavisados; o pressuposto saber dos carcereiros se volta contra a instituição. A prisão fazia parte das expectativas. Perguntada se sabia que seriam presos, Judith respondeu: "Sim, claro. Nós nos mantínhamos na expectativa de sermos presos. Fiquei espantada por terem nos permitido trabalhar por tanto tempo antes" (Idem). Uma vez presos, surge a ideia de que não haveria impedimento à missão, somente à forma de espetáculo como havia sido pensado - não por acaso, em um biIhete carinhoso, Julian convida Judith a visualizar o encarceramento como um "bom tempo descontado de qualquer eventual sentença" (BECK apud MALINA, 2008, p. 91) e uma “oportunidade", já que, mesmo decretada, a prisão não poderia ter sobre eles nenhum efeito corretivo; pelo contrário, continua Julian, "é um vigoroso momento de teatro, porque altera o plano concebido e nos leva para uma estratégia ainda mais vigorosa". O cárcere e o julgamento lhes ofereceriam ocasião de penetrar no coração do poder; seriam eles que dentro dos muros do cárcere, atuando nas instâncias de autorrepresentação do Estado no tribunal, provocariam um lento processo de saturação e corrosão de tais estruturas. De fato, a presença do Living no Fórum de Ouro Preto foi marcada por uma curiosa contracena com efeito de ultrajar a corte: no dia 30 de julho de 1971, Luke rezava em uma postura de yoga, Tom abençoava o juiz e Jimmy explicava ao juiz que a euforia de que falava na sua declaração "não 
era causada por maconha, mas por suas experiências com macumba" (MALINA, 2008, p. 147). Nesta altura não parecia haver cavalo de madeira mais seguro do que o papel de prisioneiro/vítima (como Tiradentes, mas também como Julian Beck, Judith Malina e os membros do grupo) em uma ação judicial que já repercutia com elevado impacto polêmico não somente na imprensa nacional, como na internacional. Eivada de razões políticas, a detenção dos membros do Living pela ditadura brasileira havia mobilizado ações de protesto na Europa e nos EUA. Telegramas assinados por Allen Guinsberg, Samuel Beckett, John Lennon, Jean-Paul Sartre, Yoko Ono, Michel Foucault, Bernardo Bertolucci, Jean Luis Barrault, Artur Miller, Mick Jagger, Susan Sontag, Bob Dylan, Jane Fonda, Jean-Luc Godard, Pier Paolo Pasolini, Moravia, sem que faltasse Jean Genet entre milhares de outras assinaturas recolhidas em campus universitários, fábricas, associações humanitárias, exigindo a incolumidade dos artistas e pedindo a sua libertação, resolveram as autoridades a expulsá-los por decreto (assinado em agosto pelo Presidente Médici) antes que fosse pronunciada qualquer sentença. Apontando ao mundo aquela única cena de repressão, os artistas do Living representavam para o regime um problema muito mais sério como prisioneiros do DOPS do que soltos. Porém, mesmo que o decreto de expulsão (apud TROYA, 1993, p. 12), visasse impedir o "denigramento do bom nome do Brasil no exterior", acabou viabilizando o contrário, já que logo na primeira entrevista, no desembarque em NYC, os porta-vozes do grupo cumprem voto de contar tudo que viram e ouviram dentro dos presídios brasileiros e nos outros "porões da miséria", nos quais os pobres são cotidianamente torturados, violentados e oprimidos. $A$ viagem ao Brasil, um passo perigoso ao lado dos danados da terra, havia despertado nos membros do grupo "o outro mundo: a realidade profunda, a necessidade humana no nível da sobrevivência. Foi uma inspiração que mudou nosso trabalho e, desde que nosso trabalho influenciava comunidades teatrais pelo mundo, a viagem significou uma tremenda força para o teatro em geral" (Malina, entrevistada por Zeca Ligiéro em 1991). As visões e figuras pensadas para o Legado de Caim inspiraram a produção teatral do Living nos 40 anos sucessivos, sendo que algumas (a cena do preso no pau de arara, a performance das correntes) se tornaram icônicas do teatro de resistência pela circulação mundial (inclusive em países em guerra civil, como a Palestina) de 
espetáculos como Seven meditations on political sado-masochism (1973) e Six public acts to turn violence into peace (1975). A hibridação já presente em Paradise now, entre arquétipos artaudianos e o legado político de Piscator (mestre de Judith), evolui, após a experiência brasileira, para um deslocamento estético. Do propósito (artaudiano) de performar Rituais em que o artista se oferece como vítima, o grupo passa a trabalhar no propósito (brechtiano) de performar atos públicos visando saturar os regimes de visibilidade para que a verdade se revele. Sendo a opção pela rua orgânica como o palco, tal evolução dos Rituais aos Atos Públicos destaca o trabalho europeu do Living nos anos de chumbo, quando, na contramão da maioria dos grupos militantes, tentava levar sua luta para longe da luta armada e para fora da clandestinidade, como dispositivo não violento de revelação dos conflitos e pacificação. Nesse sentido, sua peculiar compreensão do sonho de Artaud para um teatro "sem espectadores" - uma comunidade vivencial isonômica, uma experiência estética participativa - se aproxima de certas modalidades de Teatro do Oprimido, como o Teatro Invisível e o Teatro-Fórum, desenvolvidas por Augusto Boal em seu exílio na Argentina e Peru, no mesmo período. Ano da expulsão do Living e do Boal, 1971 é também o ano da ruptura estética e comportamental no percurso do Oficina, que, sob impacto do (des)encontro com o Living, parte em viagem (chamada Utropia) pelos sertões e pelo agreste, momento em que é concebido Gracias, señor em processo de criação coletiva e com táticas de apresentação em estilo agit-prop, sem anúncio, sem figurinos, sem texto - no lugar, um roteiro desenhado de ações com mapas da cidade a ser teatralizada. Essas vivências hoje soam lendárias, resumidas a uma anedótica teatral normalmente minimizada pela história política, mas devolvem uma interrogação inadiável para o campo da cultura, principalmente nesse momento, em que se sobrepõe um movimento de resistência mundial à instância de que seja feita pública análise dos acontecimentos da época da ditadura no Brasil, um desejo de partecipação que toma as ruas e ocupa as cidades. Ainda é possível pensar a revolução, a "Maravilhosa Revolução Não Violenta," como buscava o Living entre tantos utopistas no passado, em busca de um mundo melhor? E qual a função da arte e dos artistas nesta luta? 


\section{Referências bibliográficas}

ALMEIDA, M. Conversas com Zé Celso. São Paulo: Imprensa Oficial, 2012.

BARRUCC, R. O sonho de um teatro vivente: o Living Theatre. Revista Artefato, p. 333-345. Disponível em: <http://issuu.com/rizoma.net/docs/artefato>. Acesso: 19 jun. 2015.

BARTHES, R. Sade, Fourier, Loyola. São Paulo: Martins Fontes, 2005.

BATAILLE, G. O erotismo. São Paulo: Autêntica, 2011.

BECK, J.; MALINA, J. L'eredità di Caino. Torino: Centro di Documentazione Anarchica, datilografado, s/d.

The legacy of Cain in Brazil, a favela play, 8.12.1970, datilografado. Favela

Project, n. 1: Bolo de Natal para o Buraco Quente e o Buraco Frio [Arquivo "Living Theatre" do NEPAA/UNIRIO].

BECK, J. La vita del teatro. L'artista e la lotta del popolo. Torino: Einaudi, 1975.

Cadernos de trabalho manuscritos. "Living Theatre" Records, Beinecke Manuscript Library, Yale University.

BEY, $\mathrm{H}$. The temporary autonomous zone. In: Hakim Bey and Ontological

Anarchy. The Writings of Hakim Bey. Disponível em: <http://hermetic.com/bey/ taz3.html\#labelTAZ>. Acesso: 19 jun. 2015.

BINER, P. The Living Theatre. Bari: De Donato, 1968; Nova York: Horizon, 1972.

BONITO OLIVA, A. (Org.). Living Theatre. Labirinti dell'immaginario. Catálogo.

Napoli: Morra, 2003

DE CERTEAU, Michel. La prise de parole et autres écrits politiques. Paris: Seuil, 1994.

DELEUZE, G. Sacher-Masoc. O frio e o cruel. Rio de Janeiro: Zahar, 2009.

FANON, F. I dannati della terra. Torino: Einaudi, 1962.

FOUCAULT, M. História da sexualidade I. A vontade de saber. Rio de Janeiro: Graal, 1989.

FREYRE, G. Casa-grande \& senzala. Rio de Janeiro; São Paulo: Record, 2002.

GIRARD, R. La violenza e il sacro. Milano: Adelphi, 1992.

HALL, S. Hippies: una contra-cultura. Barcelona: Anagrama, 1970.

KAMINSKI, L. F. Por entre a neblina. O Festival de Inverno de Ouro Preto e a experiência histórica dos anos 70. Dissertaçao (Mestrado). Programa de Pós-Graduação em História da Universidade Federal de Ouro Preto, Mariana, 2012.

LACAN, Jacques. II rovescio della psicoanalisi. Seminari, XVII. Torino: Einaudi, 2001.

LIGIÉRO, Z. The Living Theatre no Brasil. ArtCultura, Uberlândia, v. 1, n. 1, jan. 1999.

LOPES, A. L. Living Theatre: trajetória de uma impossibilidade. Revista Folhetim, v. 4, maio 1999. 
LEMOS, V. Gracias Señor: análise de uma proposta para a atuação. Dissertação (Mestrado em Teatro) - Programa de Pós-Graduaçao em Teatro, Universidade Federal do Estado do Rio de Janeiro, Rio de Janeiro, 2000

LOPES DA SILVA, F. Freyre \& Foucault: Casa-grande \& Senzala como microfísica do poder. Revista de História e Estudos Culturais, vol. 3, n. 3, ano III, jul./ago./set. 2006.

MALINA, J. Diário. O Living Theatre em Minas Gerais. Belo Horizonte: Arquivo Público Mineiro, 2008.

The enormous despair. Diary of Judith Malina, August 1968 to April 1969. New York: Random House, 1972.

Diários e desenhos manuscritos. Living Theatre Records, Beinecke Manuscript Library, Yale University.

Entrevista com Zeca Ligièro, Nova York, 1991, datilografada [Arquivo do NEPAA/UNIRIO].

Palestra dramática para o Forum das Letras de Ouro Preto, 2011, datilografada [arquivo pessoal].

. Entrevista com Maíra Lana e Pedro de Grammont, Nova York, 2012, datilografada. In: LANA, M. Living Theatre em mo[vi]mento. Qualificação (Mestrado em Teatro). Programa de Pós-Graduaçao em Teatro, Universidade Federal do Estado do Rio de Janeiro, Rio de Janeiro, 2013.

MALINA, J.; BECK, J. Paradise now: a colletive creation of The Living Theatre written down by J.Malina and J. Beck. New York: Random House, 1971.

MARTINEZ CORRÊA, J. C. Primeiro Ato. São Paulo: Editora 34, 1998.

MIGNON, P. Jean-Louis Barrault. Le théâtre total. Monaco: Éditions du Rocher, 1999.

Paradise Now: notes. The Drama Review, vol. 13, n. 3, primavera de 1969.

PASOLINI, P. P. Trasumanar e organizzar. Milão: Garzanti, 1971.

QUADRI, F. Beck e Malina. Il lavoro del Living (1952-1969). Milão: UBULIBRI, 1982.

SILVESTRO, C. (Org.). The Living Book of the Living Theatre. Nova York: Graphic Society, 1971.

TYTELL, J. The living theatre. Art exile and outrage. Nova York: Grove Press, 1995. TROYA, I. (Org.). Fragmentos da vida do Living Theatre. 25 Festival de Inverno da UFMG, Ouro Preto, Imprensa Universitária, 1993.

VALENTI, C. Storia del Living Theatre. Conversazioni com Judith Malina. Milão: Eleuthera, 1995.

Recebido em 16/04/2015

Aprovado em 23/05/2015

Publicado em 30/06/2015 